\title{
NARRATIVAS IMIGRANTES: REPENSANDO OS “TURBULENTOS” E AMOTINADOS NAS REGIÕES DE COLONIZAÇÃO ALEMÃ *
}

\author{
IMMIGRANT NARRATIVES: RETHINKING THE "TURBULENTS" AND \\ AMOTINATES IN GERMAN COLONIZATION REGIONS
}

Patrícia Bosenbecker**

\begin{abstract}
Resumo: A colonização da região sul brasileira com imigrantes europeus foi um tenso processo de assentamento agrário, muitas vezes marcado por irregularidades na demarcação e divisão das terras, que culminou não raramente em conflitos violentos nas colônias. Revoltas, em geral, eram decorrentes de uma política de colonização deficiente e da precariedade das condições de vida, contudo, a causa dos protestos é atribuída pelas autoridades à moral dos colonos que assumiram a liderança dos motins. A partir da revisão dos principais aspectos teóricos envolvendo o tema dos motins nas regiões coloniais, especialmente demarcados por Seyferth (1999), pretendemos avaliar os perfis e papéis das lideranças do motim da colônia São Lourenço, nosso recorte empírico, e, dessa forma, buscamos compreender quem são os amotinados. Pretendemos, assim, contribuir para a compreensão das conturbadas realidades nas regiões coloniais do sul do Brasil, desvelando um cotidiano de violência e uma longa lista de irregularidades no processo de colonização.
\end{abstract}

Palavras-Chave: Colonização Privada. Conflitos. Narrativa Histórica.

\begin{abstract}
The colonization of Brazil's southern region with European immigrants was a tense process of agrarian settlement, often marked by irregularities in the demarcation and division of land, culminating not rarely in violent conflicts in the colonies. Revolts, in general, were due to a poor policy of colonization and precarious living conditions; however, the cause of the protests is attributed by the authorities to the morale of the settlers who took the lead in the riots. From the review of the main theoretical aspects of the riots in the colonial regions, especially demarcated by Seyferth (1999), we intend to evaluate the profiles and roles of the leaders of the riot of the São Lourenço colony, our empirical cut, and, in this way, we seek understand who the mutineers are. We intend, therefore, to contribute to the understanding of the troubled realities in the colonial regions of southern Brazil, revealing a daily violence and a long list of irregularities in the colonization process.
\end{abstract}

Keywords: Private Colonization. Conflicts. Historical Narrative.

\footnotetext{
* A versão aqui apresentada é uma narrativa histórica nos termos da Sociologia Histórica, construída a partir de dados de pesquisa e novas fontes documentais encontradas recentemente, especialmente sobre o pesquisado José Pons. O trabalho teve princípio na minha dissertação de mestrado, defendida em 2011, intitulada Uma colônia cercada de estâncias: imigrantes em São Lourenço/RS (1857-1877). Em um artigo denominado Colonos nos domínios de Rheingantz: uma revolta no sul do Brasil (BOSENBECKER, 2012), as discussões sobre a revolta e suas consequências foram resumidas, de forma que o texto aqui proposto pode ser considerado uma continuação desse artigo. O trabalho aqui apresentado faz parte das minhas pesquisas realizadas no doutorado com apoio da Coordenação de Aperfeiçoamento de Pessoal de Nível Superior - Brasil (CAPES).

** Pós-doutoranda em Sociologia/UFSCar e bolsista FAPESP. Doutora em Sociologia e mestre em História. Currículo Lattes: http://lattes.cnpq.br/9872024376579917.
} 


\section{Introdução}

[...] tendo-se transportado alguns objetos para uma outra casa, com o fim de salva-los do incêndio talvez de que foi Rheingantz [diretor e proprietário da colônia] ameaçado, o tenente Marinho [autoridade policial da colônia] no dia 26 de dezembro fixou as portas da casa de Rheingantz e selou-as, depois do que mandaram os colonos guardar a dita casa por uma guarda formada por colonos, ora composta de 12 , e ora de mais até o numero de 15 pessoas, que se rendiam de 24 em 24 horas, tendo ele respondente em sua casa a relação de todas as pessoas que faziam esta guarda, o que tudo se faz de combinação entre ele respondente e diversos colonos [...]. ${ }^{1}$

Uma das maiores revoltas de colonos alemães do Rio Grande do Sul ocorreu em 1867, no interior da província, onde atualmente se localiza o município de São Lourenço do Sul. ${ }^{2}$ A revolta ${ }^{3}$ contra o diretor e proprietário da colônia, o empresário prussiano Jacob Rheingantz ${ }^{4}$, ocorreu na véspera do natal de 1867 e teve consequências imediatas inusitadas. Tudo minuciosamente devassado em um processo criminal movido contra 10 "cabeças do motim", que foram presos, julgados, com direito a um recurso na instância superior, e absolvidos. $\mathrm{O}$ trecho transcrito anteriormente integra o depoimento de José Pons, uma das lideranças e provavelmente o principal articulador do motim, e revela uma das consequências imediatas à revolta: a organização de uma escolta armada para "proteger" os bens do diretor colonial, que por segurança evidentemente deixou a colônia logo após conflito.

A segunda ação imediata tomada pelo grupo revoltoso foi o leilão dos animais que pertenciam ao diretor, para que os referidos animais não morressem de fome. Houve, contudo, a delimitação de um limite no leilão, já que entre os amimais não foi vendida a vaca que

\footnotetext{
${ }^{1}$ Depoimento de José Pons dirigido ao Chefe de Polícia da Província do Rio Grande do Sul, Bellarmino da Gama e Mello, em Pelotas, em 13 de fevereiro de 1868. APERS. Comarca de Pelotas. Tribunal do Júri. Processo Judicial/Crime n. 520, 1868, cx. 006.0311. Todas as citações de fontes históricas aqui mencionadas tiveram o português atualizado.

${ }^{2}$ Nos dias atuais, a maior parte da área da antiga Colônia São Lourenço está localizada no município de São Lourenço do Sul, que foi emancipado do município de Pelotas, em 1884, processo para o qual a colônia e o seu desenvolvimento contribuíram significativamente. A área colonial, contudo, também abrangia uma parte que ficou no município de Pelotas, além de partes do seu território desmembradas mais recentemente quando da criação dos municípios de Turuçu e Cristal.

${ }^{3}$ Motim, desordem e revolta são neste artigo empregados indistintamente, sem diferenças conceituais, muito embora eu esteja ciente das objeções de Thompson, que observou que "o termo 'motim' é ferramenta de análise pouco afiada para tantas queixas e motivos particulares. É igualmente um termo impreciso para descrever a ação popular" (THOMPSON, 1998, p. 176).

${ }^{4}$ Sobre a trajetória da família Rheingantz e a construção e desenvolvimento de seus empreendimentos veja BOSENBECKER, 2017.
} 
produzia o leite consumido na casa da família proprietária da colônia. Este animal era de estimação da esposa do diretor e, por isso, foi deixada no vizinho para ser devolvida quando os donos retornassem. Ao que parece ninguém queria ser responsável pela venda do animal de estimação. Como eu já referi em outra oportunidade, ao lembrar-me dos conceitos de Thompson sobre economia moral:

O movimento da multidão de colonos levou a ações inusitadas, disciplinadas e de grandes proporções, e desta forma, para usar os termos de Thompson, nestas ações "o extraordinário é mais a moderação do que a desordem" (1998, p. 180). As atitudes, provavelmente "aprovadas por um esmagador consenso popular", usam noções de direito e manejam concepções de bem estar social nos remetendo à noção de "economia moral" de Thompson. (BOSENBECKER, 2011, p. 80).

Tais ações imediatas ao conflito poderiam buscar provocar ainda mais o diretor da colônia, contudo, é preciso observar que alguns aspectos desse conflito carecem de reflexão mais minuciosa especialmente frente ao papel dos indivíduos que o lideraram. Como evidenciou Giralda Seyferth (1999, p. 303-304), mesmo sendo clara a precariedade das condições de vida colonial, a causa dos protestos é atribuída pelas autoridades policiais ou diretores coloniais quase sempre à moral dos colonos que assumiram a liderança dos motins. Dessa noção nascem os epítetos mais utilizados para qualificar, ou desqualificar, os revoltosos como "cabeças de motim", bêbados, elementos de maus costumes, indesejáveis, arruaceiros, turbulentos e, o preferido do diretor Rheingantz de São Lourenço, maus colonos.

Este artigo, por seu turno, busca compreender quem são os amotinados, a partir da construção de seus perfis, investigando os interesses particulares e coletivos desses imigrantes. Na primeira parte deste trabalho, pretendemos revisar os principais aspectos dos motins nas regiões coloniais a partir do importante texto de Seyferth (1999), que tratou das revoltas e conflitos nas colônias de imigrantes. Em seguida, a partir de pesquisa empírica, pretendemos avaliar os perfis e papéis das lideranças do motim da colônia São Lourenço, especialmente, a partir da narrativa dos imigrantes. De maneira geral, esses motins podem nos auxiliar a compreender uma conturbada realidade nas regiões coloniais do sul do Brasil, desvelando um cotidiano de violência e uma longa lista de irregularidades no processo de colonização. 
Como sabemos, é extremamente difícil obter fontes históricas que tenham sido escritas pelos próprios colonos e que mostrem suas condições de vida. Em geral, restam apenas relatórios, abaixo-assinados e documentos oficiais das direções coloniais ou dos antigos governos provinciais. Este trabalho propõe, contudo, utilizar além desses documentos, processos criminais e inventários, e uma espécie de "carta testamento" deixada por uma das lideranças do motim. ${ }^{6} \mathrm{O}$ levantamento e cruzamento das fontes documentais foram essenciais para a construção dos perfis aqui elaboradores e da construção da narrativa de análise, que guia metodologicamente a elaboração deste texto.

\section{As reivindicações imigrantes no conturbado processo de colonização}

Em texto fundamental para o tema, Giralda Seyferth (1999) mostrou que o próprio modelo de colonização - entendido aqui como o assentamento de famílias de imigrantes europeus em pequenas propriedades, longe das grandes propriedades monocultoras do país, especialmente durante o período imperial - deu lugar a inúmeros protestos e conflitos. Uma série de falhas na política de colonização terminou por minar as expectativas de um bem sucedido sistema de imigração, especialmente, pela recorrente falta de recursos, investimentos e pelo improviso. A própria concessão das terras públicas destinadas aos estrangeiros foi motivo de conflitos, uma vez que muitas delas já tinham proprietários, legais ou não, e que o esforço político a nova legislação de terras não foi capaz de acabar com os conflitos. Após a chegada dos imigrantes nas colônias, os próprios imigrantes tinham que auxiliar na demarcação dos lotes ou na abertura de estradas, em forma de trabalho público, que lhes rendia algum pecúlio, enquanto aguardavam a liberação da pequena propriedade. Falta de medição, falta de registros e a falta de uma "caderneta", com as contas minimamente disponíveis para controle de gastos, formam o que Seyferth (1999) afirma refletir a precariedade da instalação das colônias.

\footnotetext{
${ }^{5} \mathrm{O}$ texto foi escrito por José Pons, em 10 fev. 1904, em Pelotas/RS, intitulado "Simples descrição de minha vida”. Deixo aqui assinalado os meus agradecimentos aos descendentes de José Pons, especialmente a Pedro Paulo Pons e Rogério Pons da Silva, que compartilharam comigo a história desse imigrante e gentilmente cederam uma cópia do documento original aqui descrito.

${ }^{6}$ Entre outros documentos, veja: APERS. Comarca de Pelotas. Tribunal do Júri. Processo Judicial/Crime n. 520, 1868, cx. 006.0311. s/p; e Comarca de Pelotas. Vara Cível e Crime. Processo Judicial/Ação de Força Nova, n. 144, 1903, cx. 006.0220, além de PONS, José. Simples descrição de minha vida. Pelotas, 1904. (mineo)
} 
Outro ponto, diretamente relacionado ao primeiro, é o que podemos chamar a organização do Estado na colônia, que basicamente se resume a presença do diretor colonial, que era a autoridade máxima da colônia. Por um lado, o diretor era responsável por controlar a chegada e instalação dos grupos imigrantes, a distribuição dos mantimentos, a compra de implementos, ferramentas e do assentamento dos comerciantes, da distribuição dos vales, dos recursos, e dos investimentos do Estado nas colônias, como pontes e estradas, por exemplo. Além dessas atividades, o diretor também estava autorizado a liberar ou não a saída de colonos, que eram obrigados a pedir licença da direção para deixarem a colônia. E, na falta de qualquer tipo de representação aos imigrantes, o diretor era o porta-voz das reivindicações dos imigrantes.

Por outro lado, toda e qualquer decisão tomada pelo diretor estava sujeita a aprovação das presidências das províncias ou do Ministério da Agricultura. É o que a autora chamou de "dependência do diretor em relação às autoridades provinciais e imperiais" (SEYFERTH, 1999, p. 289, grifos nossos). Com relação a este aspecto - a dependência do diretor - é preciso enfatizar que o seu oposto, ou seja, a autonomia do diretor, que a nenhuma autoridade precisava responder, como ocorreu com o diretor Rheingantz (BOSENBECKER, 2011, 2012), também causou uma série de conflitos no modelo de imigração, aqui especialmente no âmbito da colonização privada.

Avaliando a colonização da atual Brusque, em Santa Catarina, Seyferth (1999, p. 290294) encontrou 10 problemas que estavam na raiz dos motins e protestos, e excetuando conflitos por razões étnicas, a maior parte dos motins surgiu por conta da política de colonização e foram personificados na figura do diretor. Entre as razões dos conflitos estavam: 1) a demorada demarcação de lotes e abertura dos caminhos, utilizando os imigrantes como mão-de-obra mal remunerada para realização dos trabalhos; 2) o grande número de imigrantes e poucas condições de assentamento para todos; 3) o descompasso entre a administração colonial e as presidências provinciais, especialmente falta de recursos e improviso; 4) longo período de espera para os colonos na sede da colônia, gerando dificuldades e o endividamento das famílias nos comércios, gerando uma divida dupla: a colonial somada com a comercial; 5) o tempo de espera para o lote ser produtivo - não inferir a um ano; 6) dificuldades e burocracia para expedição dos títulos de propriedade dos lotes; 7) 
necessidade de autorização da direção para sair da colônia e proibição de trocas ou vendas dos lotes ou de trabalhar em outros locais para aumentar a renda; 8) dificuldades de adaptação ao novo país: clima, alimentação, etc.; 9) falta de assistência médica, novo regime alimentar, novas doentes, alta mortalidade; 10) questões religiosas e educacionais, como falta de escolas e professores ou rixas religiosas.

Os problemas avaliados pela autora estão na origem de boa parte dos conflitos entre colonos e diretores ou demais autoridades nas regiões de colonização alemã em todo o país. Analisando a revolta que ocorreu em São Lourenço, também é possível fazer associações e comparações entre os problemas das colônias do governo e as colônias de caráter privado. Em São Lourenço, palco de grande revolta, além daqueles problemas já descritos, as questões envolveram: 1) a venda dos lotes por preço maior do que acertado em contrato e os recibos recebidos com preço menor do que o pago; 2) a falta dos títulos de propriedades; 3) o não cumprimento dos contratos assinados; 4) a falta de uma escola pública; 5) o controle do diretor e a forma de tratamento dada aos colonos; 6) a construção da igreja católica da colônia; 7) o acirramento dos conflitos e o aumento das reivindicações dos colonos desde 1865, sem a devida consideração das autoridades competentes.

O último ponto é talvez crucial para entender o estopim da grande revolta. Os colonos começaram a reclamar perante autoridades provinciais, imperiais e até representações diplomáticas, mais de dois anos antes da revolta. Essa crescente de reclamações esteve marcada por vários fatores, entre os quais estão a existência de um processo judicial movido contra os colonos por falta de pagamento, a organização de uma carta com reclamações para a autoridades prussianas, a elaboração de um abaixo assinado expondo os problemas que eram enfrentados pelos colonos, e, finalmente, a tentativa de construção da igreja católica do núcleo, organizada pelo inimigo do diretor, chamado José Pons. O diretor também acusou as lideranças de discursarem em tavernas contra ele e fazerem reuniões para organizar o movimento.

Esse movimento de oposição ao diretor Rheingantz tinha alguns colonos à sua frente, que dividiam outro importante motivo para reivindicar melhores condições perante autoridades provinciais ou imperiais: a luta contra o monopólio comercial da colônia mantida por Rheingantz. Como já mostrei em outros trabalhos, alguns dos acusados presos como 
cabeças do motim - somados a outros imigrantes que também participaram dessas reivindicações, mas não foram presos, mesmo presentes do dia do motim - tinham interesses comerciais, que eram barrados pelo monopólio e exploração colonial exclusivos da família Rheingantz (BOSENBECKER, 2011; 2017).

Já em 1867, o estopim do movimento se deu em função da deliberação do governo provincial de mandar um destacamento de polícia à Colônia, formado por soldados que apenas sabiam o nome dos inimigos do diretor e por um comandante que decretou a fim das reuniões e até do jogo de cartas. Os colonos começaram a cercar o diretor, que aumentou seu poder de controle sobre os colonos, abrindo as cartas de dois imigrantes. No dia seguinte, um terço da colônia foi cobrar os seus direitos, já que o diretor não cumpria os seus deveres ${ }^{7}$, como mostrou Seyferth (1999, p. 324):

Os protestos dos colonos, individuais ou coletivos, violentos ou não, serviram para, num plano mais geral, condenar a forma como o governo imperial vinha procedendo à colonização. Independentemente da 'qualificação' camponesa ou não dos imigrantes, eles foram contratados para emigrar em nome do governo imperial, com finalidade de se estabelecer em colônias agrícolas. Concretamente tiveram de enfrentar a péssima organização das colônias, a falta de recursos para execução das obras publicas, o não-cumprimento das promessas dos agentes, interpretadas como 'contratuais', e que criaram expectativa de direitos frustrada pela realidade.

A pouca ou quase inexistente representatividade e a falta de clareza sobre os direitos dos imigrantes tornavam ainda mais difíceis a organização das reivindicações. Notamos, nesse sentido, que os problemas da colônia privada aqui trabalhados não são muito diferentes dos problemas enfrentados nas colônias do Estado. Talvez a diferença mais substancial seja que o diretor da colônia não era "fisscalizado" pelo governo provincial e não precisa responder a praticamente nenhuma autoridade sobre a forma de condução dos negócios coloniais. Contudo, também era o alvo das reclamações e a personificação de autoridade nacional na colônia.

\section{Os grandes levantes e os revoltosos}

\footnotetext{
${ }^{7}$ Para usar a expressão que está em vários trechos do processo que investigou a revolta.
} 
Apesar dos inúmeros protestos e reivindicações, em forma de denúncias na imprensa ou abaixo-assinados e cartas enviados às autoridades provinciais, a grande tensão em Brusque nunca levou a um grande levante (SEYFERTH, 1999, p. 306). Já no Rio Grande do Sul, duas das maiores colônias de imigrantes alemães, São Leopoldo, que pertencia ao Estado, e São Lourenço, propriedade privada, tiveram grandes tumultos, conforme observou Pellanda (1925, p. 33-34):

Desordens de vulto só conheceram São Leopoldo e São Lourenço, aquela com as questões de terras hoje suficientemente conhecidas e com a revolta dos Muckers; esta com as desordens motivadas pela ganância dos empresários sobre as terras vendidas aos colonos e não regularizadas.

Para a região de Brusque, Seyferth (1999) acredita que um grande levante não foi possível primeiro pelas dificuldades de organização encontradas pelos colonos, como precariedade das vias de comunicação e pelo volume de trabalho nas lavouras e no corte dos matos, por exemplo, e depois, porque não havia uma união dos diferentes grupos étnicos, apesar dos problemas comuns. Dito de outra forma, cada um dos protestes registrados em Brusque no período analisado pela autora tinham apenas um grupo étnico (badenses, bávaros, franceses, irlandeses, etc) como articulador, ou seja, havia o protesto dos alemães, o protesto dos irlandeses, o protesto dos italianos (ou ainda de diferentes estados alemães, que chegavam a se enfrentar na defesa e ataque a um dos diretores). Dessa forma, uma "ação conjunta, apesar dos problemas comuns a todos e dos constantes conflitos com a administração, não ocorreu provavelmente por causa da irredutibilidade étnica e da própria distribuição espacial dos colonos [...]" (SEYFERTH, 1999, p. 327).

A grande revolta que ocorreu em São Lourenço, por seu turno, produziu a união de mais de 200 colonos, que revezaram-se até o anoitecer, esperando o diretor aparecer na sua casa, também cede da colônia. Assim, estima-se que pelo menos um terço dos chefes de família da colônia esteve na casa de Rheingantz durante o motim. Unidos, e com ameaças ao diretor, exigirem além de clareza nas contas e no processo de medição, demarcação e distribuição das terras, que o empresário assinasse um documento comprometendo-se a agir adequadamente conforme os contratos assinados: 
[...] além dessas faltas em que estava, para com os colonos, sofriam ainda estes, o prejuízo de não terem as suas terras medidas como era de obrigação do empresário fazer, disse mais que aparecendo Rheingantz [no momento do conflito] os colonos reunidos o fizeram escrever papeis de obrigação, em que ele se comprometia, daquela data em diante, a vender-lhes as terras pelo preço na Europa anunciado e a restituir os colonos que já tivessem pago as suas terras o excedente desta quantia $[\ldots]^{8}$

De fato, os protestos dos imigrantes buscavam melhorar as precárias condições de assentamento nas regiões coloniais e denunciavam os problemas do sistema de colonização implementado pelas autoridades imperiais e provinciais, e seguido pelos empresários e colonizadores particulares, como deixa claro Seyferth (1999, p. 299-300), nesse longo trecho:

Não se trata de reivindicação fora de propósito ou simplesmente o desconhecimento dos colonos acerca da situação que enfrentariam na colônia. Esses imigrantes não vieram para o Brasil espontaneamente: foram recrutados por agentes de imigração ou seduzidos pela propagando do governo brasileiro. Os contratos estabelecidos na Europa, com aval do governo brasileiro, garantiam aos imigrantes um lote de terras públicas, comprado a prazo, subsídios para garantir a subsistência até se completar o assentamento e trabalho público com a mesma finalidade. Os subsídios e o preço dos lotes, acrescidos dos juros correspondentes, formavam a 'dívida' colonial', que deveria ser paga no prazo de cinco anos (conforme legislação em vigor). Ao fazer reivindicações desse tipo - características em quase todos os protestos registrados entre 1861 e 1881 [em Brusque - SC] - os colonos estavam apenas exigindo que o governo, por intermédio da diretoria da colônia, cumprisse suas 'obrigações contratuais'.

Contudo, independente das obrigações contraídas ou do tipo de protesto, em geral as autoridades nos mais diversos níveis não consideraram tais reivindicações legítimas (SEYFERTH, 1999, p. 328), até porque baseados na legislação vigente e na própria política de colonização, não era aceitável um perfil tumultuoso para os imigrantes-colonos, que, assim, foram reprimidos com toda a força do Estado. O modelo de colonização previa por decreto, como bem lembrou a autora, que os imigrantes deveriam ser "agricultores sadios, laboriosos e moralizados". ${ }^{9}$ E, assim, “os erros advindos de um contrato irresponsável e de uma política colonial mal planejada e sem recursos, porém, são sempre imputados aos

\footnotetext{
${ }^{8}$ Depoimento de Christiano Luís Thurow dirigido ao Chefe de Polícia da Província do Rio Grande do Sul, Bellarmino da Gama e Mello, em Pelotas, em 15 fev. 1868. APERS. Comarca de Pelotas. Tribunal do Júri. Processo Judicial/Crime n. 520, 1868, cx. 006.0311.

${ }^{9}$ Como consta, por exemplo, no item I do decreto que autorizou Caetano Pinto a introduzir imigrantes no país em nome do Império. Decreto n 5.663, de 17 de junho de 1874.
} 
imigrantes, acusados de 'maus colonizadores' com origem social pouco recomendável aos olhos da burocracia oficial [...]”' (SEYFERTH, 1999, p. 296).

Os maus colonizadores ou colonos são os tumultuosos, os turbulentos, a escória da Europa, conforme os principais epítetos nos relatórios ou correspondências entre autoridades, e, por vezes, quando não simultaneamente, são os desafetos dos diretores coloniais. De qualquer forma, é difícil para a maioria dos pesquisadores reconstruir as revoltas ou mesmo identificar os amotinados. Os próprios diretores coloniais tinham dificuldades em identificar as lideranças na maioria dos motins e apontar os culpados para que recebessem punição, que quase sempre era a expulsão das colônias (SEYFERTH, 1999, p. 327).

É, nesse sentido, que o caso da revolta de São Lourenço pode contribuir para a literatura do tema. Por ter sido uma das maiores revoltas da região envolvendo colonos alemães e o proprietário da maior colônia privada do Rio Grande do Sul, o motim de 1867 teve grandes repercussões, seja na imprensa, seja nos gabinetes do governo, e consequências, como a intervenção do governo provincial na colônia particular por mais de 2 anos, a regularização fundiária de toda a colônia, mesmo que lentamente, e, em âmbito mais geral, um processo de "revisão" e, por assim dizer, regularização das posses de terras e medições "duplicadas", que ora davam terras a fazendeiros, ora ao proprietário de São Lourenço, num processo longo e conflituoso que começou em 1869 e percorreu o final do século XIX e início do XX.

O conflito produziu além desses desdobramentos, um rico e valioso conjunto de documentos que chegaram aos dias atuais. Nesse sentido, o processo criminal que investigou a revolta é ferramenta chave para identificar as lideranças do movimento e suas possíveis atuações. É a partir desse processo, que pretendemos construir um breve perfil dos líderes da revolta.

\section{O motim de São Lourenço e o perfil dos imigrantes}

Os acusados e indiciados de serem “os cabeças do motim” da colônia São Lourenço foram os colonos José Pons, Carlos Rheinbrecht, Felipe Schneid, Guilherme Könsgen e o irmão Pedro Könzgen, Jacob Vogt, Jacob Decker, Chistiano Luis Thurow, Jeremias Ostenberg 
e André Poulsen, sendo que os dois últimos fugiram logo após instaurada as investigações. Também é preciso esclarecer que os irmãos Könzgen não eram acusados pelo motim em si, mas porque, no dia seguinte, acertaram as dívidas das terras com Rheingantz, baseados nos acordos firmados durante o protesto e, apesar de Pedro ser indiciado, ele não chegou a ser preso. Esses acusados tinham perfis um pouco diferentes, com pequena variação de idade, a maior parte deles era acatólica, mas os católicos envolvidos integravam o grupo que liderava a construção da igreja da colônia, como já foi mencionado. Todos eram agricultores ou lavradores conforme declararam, mas quatro tinham outras profisssões paralelas a condição de colono. E, evidentemente, todos são homens.

Tabela 1 - Perfil das lideranças do conflito

\begin{tabular}{l|c|c|l|c|c}
\hline \multicolumn{1}{c|}{ Liderança } & $\begin{array}{c}\text { Idade no } \\
\text { ano do } \\
\text { conflito }\end{array}$ & $\begin{array}{c}\text { Estado } \\
\text { Civil }\end{array}$ & \multicolumn{1}{|c|}{ Profissão } & $\begin{array}{c}\text { Ano em que } \\
\text { chegou na } \\
\text { colônia }\end{array}$ & $\begin{array}{c}\text { Opção } \\
\text { religiosa }\end{array}$ \\
\hline Jacob Vogt & 27 & casado & agricultor & 1865 & SI \\
\hline Carlos Rheinbrecht & 41 & casado & agricultor e alfaiate & 1866 & Acatólico \\
\hline José Pons & 36 & casado & professor & 1861 & Católico \\
\hline Felipe Schneid & 60 & casada & lavrador & 1863 & Católico \\
\hline $\begin{array}{l}\text { Christiano Luiz } \\
\text { Thurow }\end{array}$ & 34 & casado & $\begin{array}{l}\text { lavrador e vivia de } \\
\text { pequenos negócios }\end{array}$ & 1859 & Católico \\
\hline Jacob Decker & 27 & casado & agricultor e ferreiro & 1864 & Acatólico \\
\hline Guilherme Könzgen & 33 & casado & lavrador & 1862 & Acatólico \\
\hline André Paulsen & 32 & Casado & lavrador & 1862 & Acatólico \\
\hline
\end{tabular}

Embora a Tabela 1 possa auxiliar na construção de um perfil das lideranças, a mesma não é capaz de refletir a formação profissional ou a experiência dos imigrantes em sua complexidade. Nesse sentido, o perfil dos imigrantes pouco revela sobre sua formação comercial ou interesses com a migração, com exceção de Thurow, que já se declara um pequeno comerciante. $\mathrm{Na}$ sua narrativa de vida, Pons deixa claro que tinha experiência no comércio e em pequenos negócios e que sua intenção com a mudança para o Brasil era o ramo comercial. $^{10}$

\footnotetext{
${ }^{10}$ Os próximos parágrafos são de José Pons. Simples descrição de minha vida. Pelotas, 1904. (mineo)
} 
João José Hubert Pons, ou simplesmente José Pons, nasceu em 29 de março de 1832, no município de Eupen, que na época ficava na província de Aachen, reinado da Prússia, mas depois passou ao domínio da Bélgica. Tendo seis irmãos, frequentou a escola elementar na localidade de Walkorn e depois o colégio em Eupen. Durante a revolução de 1848, época na qual três de seus irmãos se alistaram, cuidou dos negócios da família, assumindo a criação de vacas leiteiras e outros animais, até o falecimento do pai e o casamento de seus irmãos. Logo após, José Pons foi para Liege, na Bélgica, para aprender a fabricação de cervejas com um cervejeiro alemão chamado Guilherme Schweitzer.

Outro objetivo de Pons com a viagem era melhorar o francês. Em 1855, casou-se com a filha do cervejeiro e passou a dirigir a cervejaria. Contudo, um dos porões usados pela fábrica havia sido comprado do prefeito da cidade, compra depois considerada ilegal, gerando um longo processo que consumiu toda a fortuna da família, obrigando José Pons a mudar-se novamente. Desta vez a mudança foi para Aachen, onde administrou a propriedade de um conde. Depois de três anos, de volta a Liége manteve um açougue, mas os negócios não satisfaziam Pons, que foi aconselhado pela família da esposa a migrar para o Brasil e abrir uma cervejaria, provavelmente com apoio dos familiares.

Assim, ele rumou para Rio Grande/RS, hospedando-se em um hotel, onde conheceu o diretor da colônia São Lourenço, o empresário Jacob Rheingantz, que o convidou para ir morar na colônia. Pons decidiu aceitar a ofertar e deixou a família no hotel para ir com Rheingantz até a colônia conhecer o local. Nessa viagem, estava acompanhado por outro imigrante, chamado Alexandre Matzenauer e juntos decidiram comprar lotes em São Lourenço. Pons interessou-se pelo lote de um colono, que tencionava vender seu prazo colonial e mudar-se para Santa Catarina. O valor era mais alto do que o Rheingantz havia oferecido e Pons foi conversar com o empresário sobre o assunto, acabando por comprar o lote das mãos de Rheingantz, porque o colono que era proprietário não havia feito os pagamentos e então não era considerado dono efetivo daquela terra. A partir de então, Pons tentou obter a escritura do terreno, mas Rheingantz não entregou a documentação definitiva.

Pons trabalhou então com gado na colônia, criando vacas leiteiras e rezes para o abate, bem como comercializando couros, com intenção de começar um negócio para mandar os couros para a Antuérpia, onde um primo dele trabalhava com este tipo de comércio. Foi 
vendendo couros para Rheingantz que os problemas aumentaram, pois o empresário somente pagava as remessas após muita pressão de Pons.

Em termos de formação e experiência profissional, a narrativa de Pons também nos auxilia a investigar as formas de educação e a formação dos imigrantes. Notamos que a narrativa não apenas reflete a experiência comercial de Pons, mas também sua formação bilíngue, o que pode ser um dado importante. A utilização do idioma francês pode ter contribuído para o diálogo de Pons com elites econômicas e políticas da província, que desconheciam o alemão, mas não o francês, ao passo que Pons ainda não falava português na época da revolta. Assim, um quesito importante na análise é a condição de alfabetizado e, também, se os acusados sabiam falar português. Apenas para um dos acusados não foi possível identificar informações sobre alfabetização e se entendia algo em português. Dos outros acusados, sete eram alfabetizados em alemão e um sabia apenas escrever o nome.

Dos alfabetizados na língua materna, dois imigrantes sabiam falar português perfeitamente e um entendia um pouco de português, outro imigrante aprendeu português posteriormente, conforme foi possível identificar, não podendo ser confirmado se já sabia ou entendia o idioma nacional na época do conflito, uma vez que estava foragido durante o processo. A alfabetização é uma ferramenta necessária e distintiva, pois auxilia no diálogo com as autoridades e elites locais, facilitando o acesso a outros grupos, fora do núcleo colonial.

Como mencionamos, a língua francesa pode ter auxiliado Pons a dialogar com as elites locais. A questão é saber se ele teria acesso a grupos fora da área colonial. É peça fundamental da oposição ao diretor e empresário Rheingantz a construção da igreja católica da colônia. É talvez nessa obra que comece a relação de grupos imigrantes da colônia com grupos das elites locais e os políticos da província. Juntamente com outros imigrantes, que Rheingantz acusa serem os irmãos Kath e Jeremias Ostenberg (embora não haja evidências de que ele era católico), José Pons tentava organizar a construção de uma igreja ou capela, a primeira no interior da colônia, como já mencionados, e, assim, Pons tomava para si uma posição de liderança, defendendo interesses dos colonos que Rheingantz não conseguia intermediar. Havia, contudo, uma igreja "brasileira", mas distante da colônia, como mostra esse trecho do texto de Pons: 
[...], no primeiro domingo que moramos lá [Colônia São Lourenço], veio toda vizinhança visitar-nos. Às dez horas disse às pessoas que já estava na hora de irmos à Igreja; e notei que todos se entreolharam surpresos, até que um deles perguntou-me onde queria eu ir na Igreja? Aqui na colônia não há Igreja. Ah! disse eu, o Sr. Rheingantz disse-me que havia Igreja e Escola aqui!

Os colonos, então, me disseram que havia uma Igreja brasileira em Boqueirão, distante 3 boas horas daqui. E o que (sic) há alguma Escola? Sim, disseram eles, aqui há um Sr. idoso, a uma hora distante daqui, este, de vez em quando leciona uma hora, e isto é tudo que temos aqui. ${ }^{11}$

Logo após a chegada da família na colônia, José Pons procurou organizar os colonos católicos na construção da referida igreja, enfrentando naturalmente o diretor da colônia, a quem competia o assunto. Havia um pequeno grupo de colonos católicos na colônia de São Lourenço, que possuía esmagadora maioria de protestantes, luteranos, reformados ou livres. Entre os católicos, estava a família do próprio Jacob Rheingantz, pelo menos a parte da família Rheingantz que estava no Brasil (BOSENBECKER, 2017). Mesmo assim, Pons reuniu 68 famílias católicas ${ }^{12}$ e doou uma pequena parte de suas terras para a construção da capela e para a formação de um cemitério, contando ainda com casa de pároco, jardim e escola, deixando um documento de doação assinado apenas em 1869. ${ }^{13}$

Mas somente o terreno não era capaz de fomentar a construção da capela. Pons, de alguma forma, entrou em contato com o Bispo em Porto Alegre, pedindo não só autorização para erguer a capela como colaboração em dinheiro. O Bispo Sebastião de Laranjeira recebeu e apoiou Pons, dando-lhe uma carta de recomendação e o nomeando diretor responsável pela construção da Igreja. Esse documento, Pons levaria ao Rio de Janeiro, onde esteve entre

\footnotetext{
${ }^{11}$ Conforme: José Pons. Simples descrição de minha vida. Pelotas, 1904. (mineo)

12 Os dados aqui apresentados são de José Pons. Simples descrição de minha vida. Pelotas, 1904 (mineo). Conforme levantamento parcial que desenvolvi a partir dos livros batismais da igreja católica de Nossa Senhora da Conceição do Boqueirão, no povoado de mesmo nome, localizado nas proximidades da colônia, existiriam 84 família católicas de origem alemã vivendo na Colônia São Lourenço entre 1858 e 1870. É importante lembrar que a igreja católica do Boqueirão recebeu os colonos católicos de origem alemã em sua totalidade pelo menos até a instalação oficial da igreja de Santa Cecília, primeira de cunho católico na colônia.

${ }^{13} \mathrm{O}$ documento original em alemão, com a devida tradução legal, está anexo ao seguinte processo: APERS. Comarca de Pelotas. Vara Cível e Crime. Processo Judicial/Ação de Força Nova, n. 144, 1903, cx. 006.0220.
} 
agosto e novembro de $1866 .{ }^{14} \mathrm{Na}$ viagem, Pons foi procurar o Imperador D. Pedro II, conforme relatou:

Trajei-me corretamente, tomei um carro e segui para o Palácio Imperial, onde imediatamente fui atendido por Sua Majestade Imperial. Em audiência, expus-lhe minha queixa e entreguei-lhe as diversas cartas, assim como a carta de recomendação do Bispo, quando ele encetou uma longa e amistosa conversa em francês comigo. A princípio falei com ele em alemão (porque eu naquela época falava pouco o português)[,] ele respondeu-me em português, então falei em francês e aí ele continuou falando francês. Eu falei-lhe à respeito de São Lourenço, etc., também que não havia Igreja e Escola, etc., etc. Ele perguntou-me onde estava hospedado, em casa particular ou hotel. Respondi-lhe que estava no Hotel Toulous, na Ouvidor, num hotel francês e no dia seguinte fui procurado no hotel pelo tesoureiro Imperial para entregar-me em nome do Imperador $200 \$ 000$ como presente para a construção da nova Capela Católica da Colônia de São Lourenço. ${ }^{15}$

Pons continuou no Rio de Janeiro angariando recursos e depois de juntar um conto e quinhentos mil réis retornou ao Rio Grande, não antes de visitar o Ministério da Agricultura para pedir doações. Quando finalmente regressou a colônia, conseguiu um cargo como professor, com nomeação pela Presidência da Província do Rio Grande do Sul, contudo o cargo foi extinto tempos depois por insistência de Rheingantz:

Enfim quando eu voltei do Rio de Janeiro em 1866 para o Rio Grande e, à conselho do Conde D'Eu, procurei um Dr. o qual me fez um requerimento em português ${ }^{16}$ dirigido ao Presidente da Província, cujo requerimento levei para a Colônia, para traduzir para o alemão, afim de que os colonos o pudessem ler e conseguir as suas assinaturas; mais ou menos 200 assinaram, deixando em Pelotas com o Notário e mais duas testemunhas para darem fé,

\footnotetext{
${ }^{14}$ Pons efetivamente esteve no Rio de Janeiro conforme os jornais da época. Ele chegou a capital imperial em 11 ago. 1866, deixando a cidade em 08 nov. 1866. Cf. Movimento do Porto. In: Diário do Rio de Janeiro. Rio de Janeiro, n. 191, p. 1v, 11 ago. 1866 e n. 267, p. 1v, 08 nov. 1866.

${ }^{15}$ Conforme: José Pons. Simples descrição de minha vida. Pelotas, 1904. (mineo)

${ }^{16} \mathrm{O}$ documento a que se refere o trecho é Abaixo-assinado dos colonos de São Lourenço, de 20 jul. 1866, encaminhado ao Governo da Província, com reinvindicações sobre a administração do diretor da colônia. AHRS. Fundo: Imigração, Terras e Colonização. São Lourenço/empresário/diretor/diversos, maço 72, caixa 37. O trecho também mostra que Pons efetivamente possuía capacidade e conhecimento para articular, dentro dos trâmites legais do país, uma oposição a Rheingantz e, assim, fazer as denúncias e tomar as providências que considerava adequadas a situação da colônia. O "Dr" a que se referiu era provavelmente um advogado pelotense. O abaixoassinado trazia cinco reclamações que perpassam os problemas de terra e sua regulamentação, a falta de escola e um pedido para demissão do diretor Rheingantz. Contudo, a narrativa de Pons difere da data do documento, que teria sido escrito em julho e teria as firmas registras em dezembro em Porto Alegre, não em Pelotas. Sobre o documento e sua repercussão veja Bosenbecker, 2011 e Iepsen, 2008.
} 
e dirigi-me à Porto Alegre, entregando pessoalmente ao Presidente o dito requerimento, o qual depois de lê-lo, disse: isto será possível! ${ }^{17}$

Após a visita de Pons à Corte, o Ministério da Agricultura enviou ao governo provincial um oficio no qual pedia para que a construção da capela tivesse a consideração que merecia do governo da província, sendo dessa forma enviado o pedido para a Assembleia Provincial, que infelizmente não atendeu aos pedidos, uma vez que caberia apenas ao empresário, enquanto proprietário e diretor da colônia, resolver a conturbada questão. O Ministério enviou novo pedido de consideração e gerou grande movimento entre departamentos do governo provincial. Segundo constava ao governo provincial, Pons já teria conseguido algum dinheiro, mas "provável que seja para a construção da casa de oração, visto ele ser Protestante". ${ }^{18}$ Mais uma artimanha de Rheingantz para encobrir os conflitos que cresciam a sua volta, além de acusar Pons de gastar os valores arrecadados para a construção da igreja em despesas pessoais. ${ }^{19} \mathrm{O}$ mesmo Ministério ainda requeria que não houvesse autorização para colonos de São Lourenço viajarem para a Corte ${ }^{20}$.

Outro aspecto que nos interessa, partindo dos pressupostos teóricos do texto de Seyferth (1999), é relativo a origem das lideranças. Em Brusque, como já referimos, os protestos eram formados por indivíduos da mesma etnia. Contudo, tomando o exemplo das lideranças do conflito de São Lourenço, podemos notar diferentes lugares de origem identificados, conforme pode ser visto no quadro a seguir:

Quadro 1 - Locais de origem das lideranças

\begin{tabular}{l|l}
\hline \multicolumn{1}{c|}{ Liderança } & \multicolumn{1}{c}{ Local de origem } \\
\hline Jacob Vogt & Koblenz, na Renânia \\
\hline Carlos Rheinbrecht & Danzig (na antiga província da Pomerânia) \\
\hline José Pons & Vila de Walhorn, Província de Liége, na Bélgica. \\
\hline Felipe Schneid & Liesenfeld, na Renânia, Prússia \\
\hline Christiano Luiz Thurow & Wismar, província de Mecklenburg-Vorpommern \\
\hline
\end{tabular}

\footnotetext{
${ }^{17}$ Conforme: José Pons. Simples descrição de minha vida. Pelotas, 1904. (mineo)

18 Resposta escrita por membros do governo sul-rio-grandense no Ofício do Ministério dos Negócios da Agricultura. AHRS. Coleção Imigração, Terras e colonização. São Lourenço/ empresário/diretor/diversos, maço 72, caixa 37. Como vimos, Pons era católico.

19 AHRS. Fundo: Imigração, Terras e Colonização. São Lourenço /empresário/diretor/diversos, maço 72, caixa 37. Correspondência do empresário Jacob Rheingantz ao Presidente da Província, em 29 jan. 1867; Correspondência do empresário Jacob Rheingantz ao Presidente da Província, em 09 mar. 1867; Correspondência com esclarecimentos do empresário Jacob Rheingantz ao Presidente da Província, em 12 set. 1867, contendo despacho do Presidente para ser enviada ao Chefe de Polícia.

${ }^{20}$ Conforme Termo do Ministério, de 22 jan. 1867.
} 


\begin{tabular}{l|l}
\hline Jacob Decker & Kreuznach, Renânia \\
\hline Guilherme Könzgen & Província da Pomerânia \\
\hline André Paulsen & ? Prússia \\
\hline Jeremias Ostenberg & Bettenhausen, Província de Hesse-Kassel \\
\hline Fonte: Elaborado pela autora a partir de: Kirchenbuch der Deutschen Evangelischen Gemeide \\
(Vila de São Lourenço), p. 162; Todten Register der Deutsch-Evangelischen Gemeide zu São \\
Lourenço. Comunidade Evangélica da Boa Vista. Óbitos. Registros do pastor Ferdnand Schick. \\
Óbito n. 7. APERS. Comarca de Pelotas. Tribunal do Júri. Processo Judicial/Crime n. 520, \\
1868, cx. 006.0311; e Processo Judicial/Crime n. 1181, 1881, cx. 006.0337. \\
\hline
\end{tabular}

Durante a revolta de 1867, Pons procurou manter-se afastado das tratativas e conversas que ocorreram entre imigrantes e o diretor Rheingantz. Em seus depoimentos no processo criminal que investigou a revolta, procurou mostrar que não tinha envolvimento com os revoltosos, como declarou:

[...] no dia em que os colonos [estavam] amotinados, em número que ele não sabe precisamente dizer, levado unicamente, por simples curiosidade, se dirigira para o lugar da reunião, tendo esta já começado em casa do empresário Jacob Rheingantz, que chegou mesmo a falar com [Dona] Rheingantz, que estava então muito assustada, [e] pedira a ele interrogado, para conter os colonos tumultuosos, que ele interrogado lhe respondera, que não era mais que um simples mestre de escola, a quem nem uma influência exercia sobre os mesmos. ${ }^{21}$

Em outros momentos de seus depoimentos mostrava desconhecer como havia surgido a revolta, alegando não saber quantos colonos participaram, mas chegou a declarar que o movimento não tinha intensão de atentar contra a vida de Rheingantz, pois "[ouviu] dizer unicamente com o fim de assustarem a Rheingantz, que é muito medroso, e diziam que o matariam, e lhe incendiariam a casa, mas pelo contrário, nada lhe fariam se ele aparecesse".22 Pons mostrou-se um articular importante em termos políticos e econômicos, centralizando o que podemos chamar de sistema de oposição contra o diretor colonial, mesmo que nas suas declarações durante a investigação criminal sejam por vezes dúbias.

Depois de preso como líder da revolta e levado para a cidade de Pelotas, Pons relatou:

Lá continuou mais alguns dias o inquérito e tivemos que ficar lá até julho, quatro meses, onde sofremos injustamente quatro meses. Recebi uma carta de pesar do Bispo de Porto Alegre, mesmo assim não adiantou; eu lutava por

21 Interrogatório de José Pons durante julgamento, em 20 jun. 1868. APERS. Comarca de Pelotas. Tribunal do Júri. Processo Judicial/Crime n. 520, 1868, cx. 006.0311. s/p. Grifos nossos.

22 Depoimento de José Pons, em 18 fev. 1868. APERS. Comarca de Pelotas. Tribunal do Júri. Processo Judicial/Crime n. 520, 1868, cx. 006.0311. s/p. Grifos nossos. 
uma causa pela coletividade e devia receber uma recompensa! Uma causa pela qual o próprio genro do Imperador, o Conde D`Eu, aconselhou o que fazer! Este era o agradecimento! Com isto eu havia gasto a minha pequena fortuna. Deixei minha mulher com oito filhos pequenos na maior miséria, sem um auxílio e na grande mata-virgem e eu preso entre quatro paredes por causa d'aquele trapaceiro. ${ }^{23}$

Segundo Pons, o segundo júri, depois da apelação do Juiz de Direito de Pelotas para o Tribunal da Relação no Rio de Janeiro, ocorreu seis meses depois do julgamento inicial. Todos foram novamente absolvidos.

\begin{abstract}
Os carros dos colonos já estavam em nossa espera quando saímos da casa da liberdade; reunimos a nossa bagagem e assim seguimos para a colônia!!! Aqui fomos recebidos com grande alegria e satisfação pelos nossos mais íntimos. Mas agora era necessário começar novamente; para uma família quase na miséria, eu recebi novamente a minha Escola, mas o rendimento desta era insuficiente, pois os colonos moradores d'aqui eram muito pobres e pagavam apenas a mensalidade de 4000 (2 patacas) que era demais para morrer, e muito pouco para viver! Eu lecionava em duas escolas, três dias em minha casa, três dias na Picada Quevedos, (distante 3 horas). Enfim, eu fiz o que me era possível.
\end{abstract}

Pons acabou organizando uma nova comissão, formada por três pessoas para a construção da igreja de Santa Cecília, que realmente foi construída nas suas terras. ${ }^{24}$ Sua intenção era voltar para a Europa, mas os filhos já estavam se encaminhando, ou seja, constituindo casamentos, suas próprias famílias e abrindo negócios, e ele tinha receios de enfrentar a viagem. Ele decidiu, então, ficar na colônia e continuar com o comércio de animais, no qual contava com a ajuda dos filhos. Foi nesse ramo que ele trabalhou até pelo menos 1890, também produzindo cerveja para comercializar na colônia, até que vendeu a colônia e foi morar com uma filha, em Pelotas, onde manteve o comércio da produção colonial.

Primeiramente, seus negócios eram realizados em parceria com os filhos, até que desentendimentos entre ele e os filhos encerrassem definitivamente o negócio. Mais tarde, ainda comprou um lote, na localidade do Retiro, no município de Pelotas, onde passou a plantar para vender a produção localmente. Após a morte da mulher e novas rixas com os

\footnotetext{
${ }^{23}$ Conforme: José Pons. Simples descrição de minha vida. Pelotas, 1904. (mineo)

${ }^{24}$ APERS. Comarca de Pelotas. Tribunal do Júri. Processo Judicial/Crime n. 520, 1868, cx. 006.0311. s/p; e Comarca de Pelotas. Vara Cível e Crime. Processo Judicial/Ação de Força Nova, n. 144, 1903, cx. 006.0220.
} 
filhos, Pons acabou vendendo quase tudo que tinha e foi morar com a filha Hortência, na casa de quem escreveu em 10 de fevereiro de 1904, um tipo de carta testamento, que intitulou "simples descrição de minha vida", documento que usamos neste trabalho.

Assim, após o julgamento em segunda instância, os acusados que estavam presos foram liberados e regressaram a colônia. Embora, alguns autores argumentem que eles teriam sido expulsos, nossas pesquisas mostram que eles permaneceram na colônia, inclusive os dois imigrantes foragidos durante o processo, que também voltaram a São Lourenço tempos depois da revolta. O Quadro 2, a seguir, mostra o que ocorreu com os colonos que foram acusados de liderarem a revolta, após o retorno a colônia.

Quadro 2 - Situação após a revolta

\begin{tabular}{|c|c|}
\hline Liderança & Observações: \\
\hline André Paulsen & $\begin{array}{l}\text { Voltou à colônia meses após o conflito. Ainda vivia na colônia com sua } \\
\text { família em } 1881 \text {. }\end{array}$ \\
\hline Carlos Rheinbrecht & Ainda não foram encontradas maiores informações \\
\hline Christiano Luiz Thurow & $\begin{array}{l}\text { Deixou a colônia antes de } 1875 \text { para construir uma casa comercial na vila } \\
\text { mais próxima, Boqueirão, onde faleceu em } 12 \text { mar. } 1906 \text {. }\end{array}$ \\
\hline Felipe Schneid & $\begin{array}{l}\text { Faleceu em 1869, logo após retornar a Colônia (provavelmente voltou } \\
\text { doente da prisão). A viúva de Felipe tratou da regularização do lote da } \\
\text { família. Deixou grande descendência na região colonial de São Lourenço. }\end{array}$ \\
\hline Guilherme Könzgen & $\begin{array}{l}\text { Ainda vivia na colônia em 1881, quando foi testemunha em um processo } \\
\text { que investigou Paulsen, seu antigo amigo, compadre e vizinho. }\end{array}$ \\
\hline Jacob Decker & $\begin{array}{l}\text { Regressou à Colônia após a revolta, falecendo na vila do Boqueirão, em } 25 \\
\text { fev. } 1926 .\end{array}$ \\
\hline Jacob Vogt & Ainda não foram encontradas maiores informações. \\
\hline Jeremias Ostenberg & $\begin{array}{l}\text { Retornou a São Lourenço algum tempo depois da revolta, quando os } \\
\text { colonos tiveram seus lotes regularizados. Faleceu na colônia em } 15 \text { sep. } \\
1873 \text {. }\end{array}$ \\
\hline José Pons & $\begin{array}{l}\text { Vendeu seu lote colonial em 1890, quando deixou São Lourenço e foi } \\
\text { morar em outra área colonial de Pelotas. Faleceu na Colônia Santa Eulália, } \\
\text { em } 27 \text { out. } 1905 \text {. }\end{array}$ \\
\hline Peter Könzgen & $\begin{array}{l}\text { Não consta nos autos a razão de não ter sido preso. Vivia na colônia, onde } \\
\text { faleceu em } 18 \text { jun. } 1874 \text {. }\end{array}$ \\
\hline \multicolumn{2}{|c|}{$\begin{array}{l}\text { Fonte: Elaborado pela autora a partir de: Kirchenbuch der Deutschen Evangelischen Gemeide (Vila de São } \\
\text { Lourenço), p. 162; Todten Register der Deutsch-Evangelischen Gemeide zu São Lourenço. Comunidade } \\
\text { Evangélica da Boa Vista. Óbitos. Registros do pastor Ferdnand Schick. Óbito n. 7. APERS. Comarca de Pelotas. } \\
\text { Tribunal do Júri. Processo Judicial/Crime n. 520, 1868, cx. 006.0311; e Processo Judicial/Crime n. 1181, 1881, } \\
\text { cx. 006.0337. Inventário de Pedro Könzgen. APERS. Comarca de Pelotas. Juízo de Órfãos da Cidade de Pelotas. } \\
2^{\circ} \text { Cartório de Órfãos e Ausentes, ano 1875. }\end{array}$} \\
\hline
\end{tabular}

O perfil e o epíteto de turbulento, entretanto, ainda perseguem as antigas lideranças da revolta, se solidificando na memória e história local, especialmente para Pons. Utilizamos qualitativamente a narrativa de vida de José Pons, como forma de elucidar alguns pontos 
sobre a história da revolta dos colonos de São Lourenço. Apesar de liderança colonial bastante ativa e articulador político, e, de certo modo, religioso, Pons ainda continua a ser caracterizado como agitador, como ocorreu em livro recente, no qual o pesquisador Edilberto Hammes (2010, v. 2, p. 63), escreveu:

[...] José Pons continuava agitando o ambiente católico, quanto tentava interceder, em setembro de 1888 - muitos anos depois de criar os primeiros problemas - junto ao bispo do Rio Grande do Sul, d. Sebastião Dias Laranjeira, para transformar a capela de Santa Cecília, situada na esquina da Picada (dos) Moinhos com Boa Vista, em freguesia. Com todo o seu passado e sua fama, aliados ao falecimento desse bispo alguns dias antes, claro nada conseguiu [...].

Pons é uma figura emblemática da constituição da colônia, um dos principais opositores ao colonizador, diretor e empresário Jacob Rheingantz, Pons conseguiu construir uma igreja para a comunidade católica local, que era minoritária entre os imigrantes alemães então assentados na colônia, mas era também a religião da família Rheingantz no Brasil. Procurando ocupar espaços até então não reivindicados pelas lideranças imigrantes do sul do Rio Grande do Sul, especialmente na região de Pelotas, o imigrante belga acabou por encontrar grandes dificuldades e forte oposição das elites imigrantes alemãs já estabelecidas.

\section{Considerações finais}

Neste texto, relembramos uma importante discussão teórica-metodológica sobre violência e conflitos em zonas coloniais da região sul do país, a partir da ocorrência de motins ou revoltas nas colônias de imigração alemã. Baseado no trabalho de Seyferth (1999), discutimos a relação entre as autoridades nacionais e diretorias coloniais e os próprios imigrantes no interior de um processo de colonização mal planejado e que apresentou ao longo do tempo várias irregularidades, produzindo assim conflitos que perpassaram tanto a administração das colônias quanto as disputas pela terra e sua regularização. Enquanto a autora trabalhou mais especificamente com a colônia de Brusque, de propriedade do governo, propomos avaliar uma colônia privada e, assim, oferecer um comparativo entre as duas formas de administração. 
Se em Brusque foram realizados vários pequenos conflitos, em geral com apenas uma etnia de imigrantes presentes, quase todos direcionados contra o diretor colonial, personificação da autoridade máxima da colônia, em são Lourenço ocorreu um grande conflito, com a participação de colonos de diversas origens, visando também diretamente o diretor colonial, que também era o comerciante, o empresário, o dono da terra, etc. Também em São Lourenço, foi possível observar que algumas lideranças do conflito tinham ambições comerciais, barradas pelo monopólio da diretoria da colônia.

Uma característica singular da revolta de São Lourenço foi o acesso a elites não imigrantes, como advogados e religiosos que puderam intermediar as necessidades dos imigrantes e as demandas do Estado. Nesse sentido, ainda persiste a pergunta sobre a condição que os imigrantes tinham de dialogar com outros grupos, ou ainda com políticos, e apresentar suas reivindicações, quando aqueles que deveriam intermediá-las não cumpriam essa função. Assim, as formas de organização dos imigrantes nas colônias ainda são investigações pertinentes nos estudos migratórios. Nesse sentido, a perspicácia de Pons é, sem duvidas, característica muito particular da grande revolta do extremo sul.

Por outro lado, procuramos contribuir com as narrativas imigrantes, cruzando fontes documentais variadas e buscando informações históricas dos agentes que lideraram as revoltas. Escritas dos próprios imigrantes são, de certa forma, raras, mas quando disponíveis fornecem dados e detalhes cruciais na construção de perfis e na produção de novas narrativas sobre os conflitos. Assim, produzimos um perfil mais amplo das lideranças do movimento, acrescentando uma narrativa sobre a história de vida de uma liderança em especial, que serviu de base para nossa análise.

\section{Referências bibliográficas}

BOSENBECKER, Patrícia. Três gerações de empreendedorismo: capital e laços sociais entre Brasil e Alemanha a partir do estudo de caso da família Rheingantz. Tese (Doutorado em Sociologia). Porto Alegre: Universidade Federal do Rio Grande do Sul UFRGS, 2017. 
Colonos nos domínios do diretor Rheingantz: uma revolta no sul do Brasil. Métis: História e cultura-UCS. Caxias do Sul, v. 11, n. 22, p. 41-65, 2012.

. Uma colônia cercada de estâncias: imigrantes em São Lourenço/RS (1857-1877). Dissertação (Mestrado em História). Porto Alegre, PPG-História/UFRGS, 2011.

COARACY, Vivaldo. A Colônia São Lourenço e o seu fundador Jacob Rheingantz. São Paulo: Saraiva, 1957.

HAMMES, Edilberto L. São Lourenço do Sul: radiografia de um município - das origens ao ano 2000. São Leopoldo: Studio Zeus, 2010. 4 vols.

IEPSEN, Eduardo. Jacob Rheingantz e a colônia São Lourenço: da desconstrução de um mito à reconstrução de uma história. Dissertação (Mestrado em História). São Leopoldo: Universidade do Vale do Rio dos Sinos, 2008. 280 pg.

KOLling, Nilo Bidone. A presença teuta a partir de São Lourenço do Sul/RS. Anais do $9^{\circ}$ Seminário Nacional de Pesquisadores da História das Comunidades Teuto-brasileiras (2006). Entre vales e serras: fronteiras. São Leopoldo: Casa Leiria, 2008. p. 867-892. CDROM - ISBN: 987.85.61598.01.3.

MONSMA, Karl. Histórias de violência: inquéritos policiais e processos criminais como fontes para o estudo de relações interétnicas. In: DEMARTINI, Zelia; TRUZZI, Oswaldo (orgs). Estudos Migratórios. Perspectivas metodológicas. São Carlos: EdUFSCar, 2005. p. 159-221.

PELLANDA, Ernesto. A colonização alemã no Rio Grande do Sul. Porto Alegre: Oficinas gráficas da Livraria do Globo, 1925.

RHEINGANTZ, Carlos Guilherme. Colônia de São Lourenço. Breve Histórico de sua fundação, extrahido das notas do archivo de seu fundador Jacob Rheingantz. IN: RODRIGUES, Alfredo Ferreira. Almanak literário e estatístico do Rio Grande do Sul. Porto Alegre: Pinto e Cia/Livraria Americana, 1909. p. 143-164.

ROCHE, Jean. A colonização alemã e o Rio Grande do Sul. Porto Alegre: Ed. Globo, 1969. SEIXAS, Xosé Manoel Núñes. Modelos de loderazgo en comunidades emigradas. Algumas reflexiones a partir de los españholes en América (1870-1940). IN: Bernasconi, Alicia e Frid, 
Carina (ed.) De Europa a las Américas. Dirigentes y liderazgo (1880-1960). Buenos Aires: Editarial Biblos. 2006.

SEYFERTH, Giralda. Colonização e Política imigratória no Brasil Imperial. IN: SALLES, Teresa; SALLES, Maria do Rosário R. Políticas migratórias: América Latina, Brasil e brasileiros no exterior. São Carlos: EdUFSCar/Editora Sumaré, 2002. p. 79-110.

. Colonização e conflito: estudo sobre "motins" e "desordens" numa região colonial de Santa Catarina no século XIX. In: SANTOS, José Vicente Tavares dos (org). Violências no tempo da globalização. São Paulo: Hucitec, 1999. p. 285-330.

THOMPSON, E. P. Costumes em comum. Estudos sobre a cultura popular tradicional. São Paulo: Companhia das Letras, 1998.

WITT, Marcos. Em busca de um lugar ao sol: estratégias políticas, imigração alemã, Rio Grande do Sul, Século XX. São Leopoldo: Oikos, 2008. 